\title{
減圧速度と発泡温度の相関性に基づく発泡制御
}

\author{
村 谷 圭 市*1 $・$ 新 保實 ${ }^{* 2}$ 宮 野 靖*2
}

\section{Foam Control based on Correlation of Decompression Rate and Foaming Temperature}

\begin{abstract}
Muratani, Keiichi*1/Shimbo, Minoru*2/Miyano, Yasushi*2
In this paper, the correlation between the foaming temperature and the decompression rate (decompression time) of the cell density, the number of cells per unit volume remaining in foamed plastics, will be discussed. The foaming was carried out by the following method. The blowing agent was soaked into the solid resin at high pressures under temperatures higher than the glass transition temperature of the resin. After the foaming agent reached its saturation state, cell nucleation and cell growth were accelerated by decompression. Finally, cell growth was halted by cooling. A device that can accurately control temperature and the decompression rate was designed, produced and verified for accuracy prior to this investigation. Polystyrene (PS) specimens were foamed under various foaming temperatures and decompression rates using the above-mentioned method. The following results were obtained. (1) Cell density of foamed PS shows time and temperature dependence as follows. The cell density increases when the decompression rate is quick, i.e. the decompression time is shortened at low foaming temperatures, and cell density decreases when the decompression rate is slow, i.e. decompression time is lengthened at high foaming temperatures. (2) Correlation is maintained between the temperature dependence and time dependence of the cell density of foamed PS, and it can be expressed with one master curve. (3) Based on this correlation, it is possible to predict the required foaming conditions of plastics having arbitrary cell densities.
\end{abstract}

Key words : Microcellular Plastics/Cell density/Viscoelastic behavior/

Time-temperature equivalent law

\section{1. 緒言}

近年，微細気泡を有した発泡プラスチックの一種である マイクロセルラープラスチック (Microcellular Plastics : 以下 $\mathrm{MCP}$ と省略する) の研究, 開発が多くの研究者によ り行われている。 その結果, MCP の発泡制御において, いくつかの重要な制御因子が明らかになりつつある。また， 成形技術に関しても様々な研究機関で連続成形機やバッチ

${ }^{* 1}$ 金沢工業大学 新保研究室 博士後期課程

松任市八束穂 3-1 石川リサーチパーク内（９24-0838） Graduate School, Kanazawa Institute of Technology 3-1, Yatsukaho, Matto, Ishikawa 924-0838, Japan

*2 金沢工業大学大学院 高度材料科学研究開発センター

Advanced Materials Science R\&D Center, Kanazawa Institute of Technology 2003.5.1 受理
式成形機を用いた研究，開発を行っており，それらの成形 法も徐々に確立されつつある ${ }^{1)-5)}$.このように MCP の成 形における制御因子の解明や，成形技術の開発が鋭意行わ れているが, 実際の発泡体内部の気泡径や単位体積当りに 含まれる気泡数 (気泡密度) はともに目標とする值に達成 していないのが現状である ${ }^{6) \sim 8}$. その理由として, 気泡核 生成・成長の機構の不明瞭さに加え, 発泡における制御因 子を正確に実現化する装置の開発が困難であることや温度 の違いにより挙動が変化するといったプラスチックの複雑 な粘弾性特性が一要因であると考えられる.

$\mathrm{MCP}$ の基本的な発泡原理は，発泡させたいプラスチッ クの中に物理的発泡剂として二酸化炭素や窒素を高圧下で 含浸飽和させ，この試料を減圧あるいは温度変化を与える ことにより引き起こされる発泡剤の急激な熱力学的不安定 現象が発泡剂と樹脂の相分離を誘起することを基礎として 
いる.この際の気泡の基となる気泡核の発生率は，発泡郕 含浸量, 発泡温度, そして飽和圧力と周辺圧力の圧力差が 大きい程多くなることは核生成理論から推測される2. 近 年，これらの因子に加え減圧速度の効果についても検討さ れ, 気泡核の発生数は発泡剂含浸後, 発泡温度がプラスチッ クのガラス転移温度以上の温度で, 圧力差が大きく, かつ 急速減圧であるほうが増え, 微細な気泡径を有する発泡体 が得られることが報告されている9,10). プラスチック発泡 体に残る最終的な気泡の数は, まず気泡核生成が行われ, その後気泡は成長し, 気泡同士の干渉, 破泡, 合一等の現 象を伴い, 樹脂内の発泡剤が気泡核生成や成長に寄与しな くなる量以下になった場合，あるいは樹脂の温度がガラス 転移温度以下になった場合に停止し, 生成した核数より少 なくなると考えられる。このような気泡の成長はプラス チックのガラス転移温度以上の粘弾性領域あるいはゴム状 領域で行われ, 気泡停止は逆にガラス転移温度以下のガラ ス状領域で行われることから, 発泡体に最終的に残る気泡 数はプラスチックの粘弾性特性と関係があることが推測で きる. 発泡に打いて, 生成した核数と最終的な気泡数を比 べた場合, 最終的な気泡数が核数に比べ少なくなるといっ た事実については，すでに報告されている ${ }^{11,12)}$. 滅圧速度 が速い（減圧時間が短い）時は初期気泡核数が多く, そし て遅い時は初期気泡核数が少なく, その後気泡の成長が始 まりさらに新たな気泡核生成・成長を引き起こしながら, 気泡の合一等を伴って気泡成長が停止されるものと考元ら れる。すなわち, 減圧時間が短い（减圧速度が速い）場合 は, 初期気泡核数が多く, 減圧時間が長い場合は初期気泡 核数が少なく, その後の気泡成長に抢いては, 温度が高い 程気泡の合一等の確率が高くなり, 温度が低い場合程気泡 の合一等の確率が低くなるものと思われる。このような発 泡温度と減圧速度の相関関係を明らかにすることにより， 任意の気泡密度を有する発泡体を成形する際の成形条件の 予測や，予測した成形条件が現状の制御装置で実現可能か 等の判断の一助とすることができる.

本研究は, 試料にガラス転移温度以上の高温下で, 発泡 凨を高圧で飽和含浸させ，その後減圧と共に気泡核生成， 気泡成長を行い，冷却により気泡成長を停止する発泡プロ セスを取り上げ，発泡体に最終的に残る気泡密度について， 含浸圧力から大気圧までの減压速度（減圧時間）と発泡温 度の関係を検討した。まず，検討方法として，減圧制御と 温度制御を的確に行えるバッチ式成形装置を設計, 試作し た。ついで, 本装置を使用し, 非晶性樹脂であるポリスチ レン樹脂を用いて, 種々の発泡温度, 一定圧力の下で種々 に減圧速度を変えて発泡成形を行った。そしてポリスチレ ン樹脂発泡体内部の気泡密度に対する発泡温度と減圧速度, つまり減圧時間の関係について調查した。

\section{2 . 評価装置}

\section{1 評価装置}

本研究では, 発泡温度と減圧速度つまり減圧時間の関係 を検討するため温度と減圧速度を正確に制御できる図 1 に 示すような装置を設計，製作した。この図に示すように， 圧力容器に熱電対 (直径 $1.6 \mathrm{~mm}$ の保護管付き $\mathrm{K}$ 熱電対), 圧力計（ダイニスコ製 NP 431 型）を取り付け圧力容器内
の温度変化と圧力変化を定量的に数值化できるようにした。 そして, 減圧時の発泡郕の排出並びに容器自体の温度制御 が迅速に行えるように圧力容器内の容積を小さくした。ま た，発泡後の試料の取り出しや冷却等を迅速に行えるよう にするため, 本装置では圧力容器の上蓋を油圧プレス機で 押さえる機構とした。

\section{2 評価装置の特性評価}

本装置の減圧速度はバルブの開閉度により制御した。本 装置において減圧速度を任意に制御することができるかを 評価するため減圧速度の測定を行った。減圧速度の測定は, 種々の温度の下で, 圧力を $15 \mathrm{MPa}$ と一定にし, 減圧バル ブの開閉度を 3 段階に変化させて行った.

圧力 $15 \mathrm{MPa}$ から減圧した場合の減圧速度の測定結果を 図 2 に示す. 同図には各減圧状態に対応する圧力容器内の 発泡剂の温度変化を $95^{\circ} \mathrm{C}$ からの場合について併記してい る.この図に示すように減圧状態はいずれの場合において も約 $5 \mathrm{MPa}$ 近傍で直線性を欠くものとなっている. しか しながら, 同図に示す減圧に伴う圧力容器内の温度変化は, 減圧状態がもっとも緩やかな場合に扔いても，15 MPa か ら $5 \mathrm{MPa}$ までで既に約 $30^{\circ} \mathrm{C}$ 程度になっていることが確認 できる。後述するように，本実験に用いた試料厚さが薄く, 圧力が $5 \mathrm{MPa}$ に達したときは既に試料が泠却され，気泡

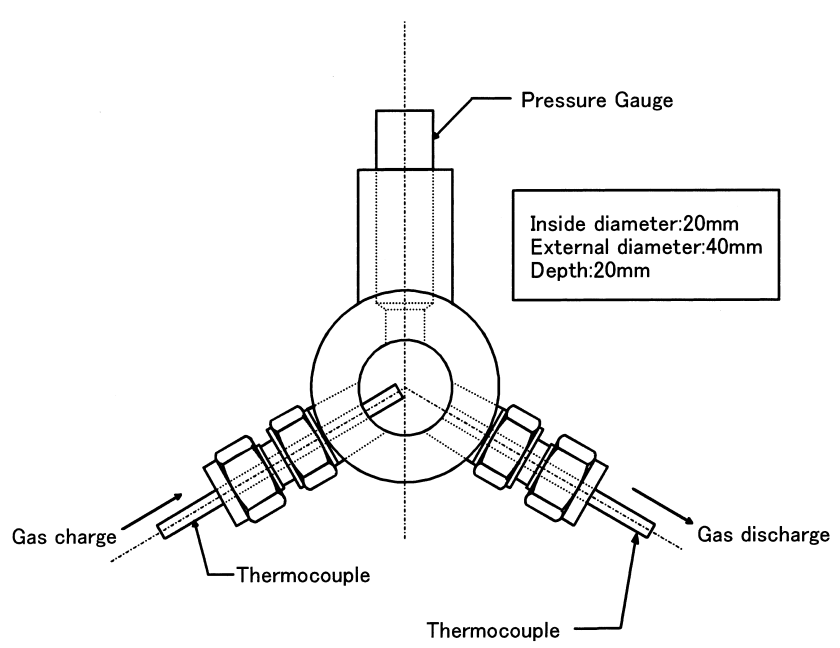

Fig. 1 Schematic device of pressure vassel for foaming

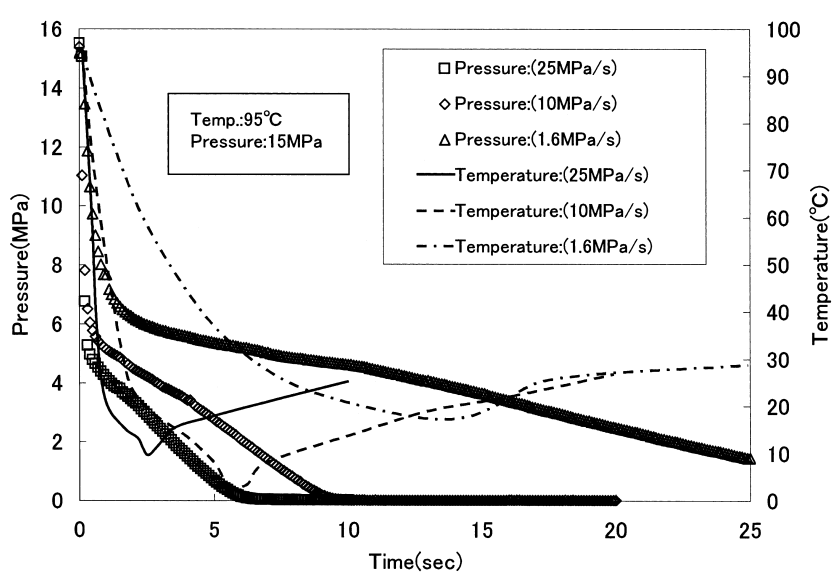

Fig. 2 Change of temperature and pressure in pressure vessel under decompression 


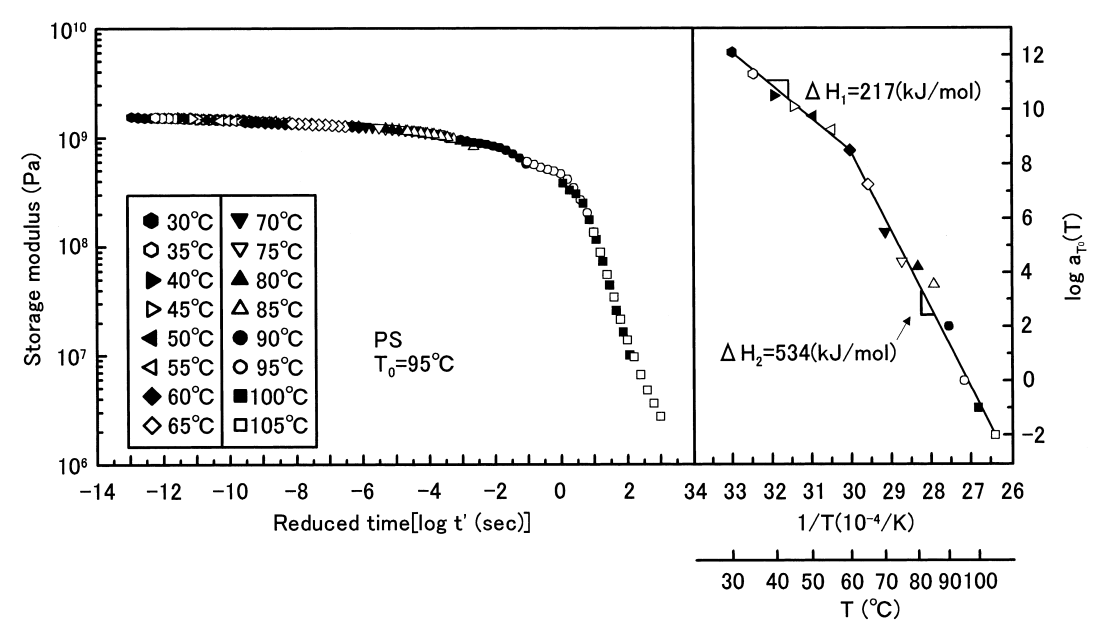

Fig. 3 Master curve and time-temperature shift factor of PS

の成長が停止し, かつ発泡実験においても得られる発泡体 内部構造に再現性がみられることから, 減圧速度を $5 \mathrm{MPa}$ までの傾きで評価を行った。この結果, $25,10,1.6 \mathrm{MPa} / \mathrm{s}$ の 3 つの減圧速度を設定することができた。

\section{3 . 発泡実験}

\section{1 供試材料}

本研究では供試材料として, ポリスチレン樹脂（分子量 約 23.5 万, 以下 PS と省略する) を使用した. 本実験で

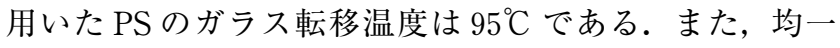
な発泡体を成形するため, 厚さ方向に極力温度分布が生じ ず，かつ冷却が迅速に行えるように試験片は厚さの薄いも のを用いた，未発泡時の試験片は縦 $15 \mathrm{~mm}$, 横 $15 \mathrm{~mm}$ そ して厚さが $0.14 \mathrm{~mm}$ の寸法とした.

図 3 にPSの譻蔵弾性係数のマスター曲線を示す.PS の貯蔵弾性係数は温度を $30 \sim 105^{\circ} \mathrm{C}$ までを 16 水準, そし て負荷周波数を $0.1 \sim 10 \mathrm{~Hz}$ までを 11 水準変化させ, 引張 負荷で測定した。同図の左側の曲線は縦軸にPS の貯蔵弾 性係数, そして横軸に周波数の逆数つまり時間をとり, 上 述の条件で得られた貯蔵弹性係数を温度 $95^{\circ} \mathrm{C}$ の值を基準 とし， $95^{\circ} \mathrm{C}$ より温度の低い值は短時間側に， $95^{\circ} \mathrm{C}$ よ温 度の高い值は長時間側に時間軸に平行にそれぞれ重なり合 うように移動させて作成したものである。これにより, PS の貯蔵弾性係数に関して一本のマスター曲線を得ることが できた。また，右側の図は移動させる際の移動量を縦軸に， 横軸に温度の逆数をとり，マスター曲線を作成した際の移 動量を示したものである.この図に示すように, PS の貯 蔵弾性係数の時間-温度移動因子はアーレニウス型で近似 できることがわかる．このことから PS の貯蔵弾性係数に は時間一温度換算則が成立することがわかる。

\section{2 実験方法}

発泡温度と減圧速度の相関関係について検討するため, 前述した評価装置を用いて発泡成形を行った. 発泡プロセ スは種々あるが，ここでは試料にガラス転移温度以上の高 温下で, 発泡剂を高圧で飽和含浸させ, その後減圧と共に 気泡核生成，気泡成長そして冷却により気泡成長を停止す るプロセスを取り上げた。このプロセスでは, 発泡剂の含 浸温度と発泡温度は同じものとなり, 試料の厚さ方向に温
Table 1 Experimental conditions

\begin{tabular}{l|c}
\hline Soaking time $(\mathrm{h})$ & 2 \\
\hline Soaking pressure $(\mathrm{MPa})$ & 15 \\
\hline Foaming temperature $\left({ }^{\circ} \mathrm{C}\right)$ & $80,85,90,95,100,105,110$ \\
\hline Decompression rate $(\mathrm{MPa} / \mathrm{s})$ & $25,10,1.6$ \\
\hline
\end{tabular}

度分布が無く, 気泡の成長が一様に行われ, 気泡径の均一 な発泡体を成形することができる．発泡実験は種々の発泡 温度, 一定の圧力下で, 種々に減圧速度を変化させて行っ た．表 1 に発泡害験条件を示す。この表に示すように，発 泡温度については, ポリスチレン樹脂のガラス転移温度が $95^{\circ} \mathrm{C}$ であることから, $95^{\circ} \mathrm{C}$ を基準に $\pm 15^{\circ} \mathrm{C}$ の 7 水準とし た。 そして, 同一条件で 3 回以上の発泡実験を行い, 再現 性を確認した。なお，物理的発泡剤として二酸化炭素を使 用した。

発泡体の気泡径および気泡密度は, 発泡体内部構造を走 査型電子顕微鏡 $(\mathrm{SEM})$ で撮影し, このSEM 写真を画像 解析することにより求めた ${ }^{13)}$.

\section{4. 結果および考察}

\section{1 気泡密度に及ぼす減圧速度}

図 4 に発泡温度 $95^{\circ} \mathrm{C}$ で減圧速度を変化させたときのポ リスチレン樹脂 (PS) の発泡体内部の SEM 写真を示す. 同図の (a) は減圧速度 $25 \mathrm{MPa} / \mathrm{s}$ ，（b) は減圧速度 $10 \mathrm{MPa} / \mathrm{s}$ そして (c) は減圧速度 $1.6 \mathrm{MPa} / \mathrm{s}$ の場合の発泡体内部構造 を表している.これらの SEM 写真から減圧速度が遅い, つまり減圧時間が長くなるほど気泡径は大きく, 気泡密度 が小さくなる傾向が見られる.これらの傾向を詳しく検討 するため, 同図に示した SEM 写真を画像解析し, 気泡径 および気泡密度を算出した。

図 5 に発泡温度 $95^{\circ} \mathrm{C}$ で減圧速度を種々に変化させたと きのPS 発泡体の気泡径分布を示す. 同図は縦軸に総気泡 数と各気泡径に占める気泡数の比をとり, 横軸に気泡径を とり, 減圧速度を変化させたときの各気泡径が発泡体内部 に占める割合を示している。この結果から減圧速度が遅い ほど気泡径は大きくなり，広範囲に分布することがわかる。

図 6 に種々の発泡温度の下で, 減圧速度を変化させたと きの PS 発泡体の気泡密度を示す。同図は縦軸に発泡体内 


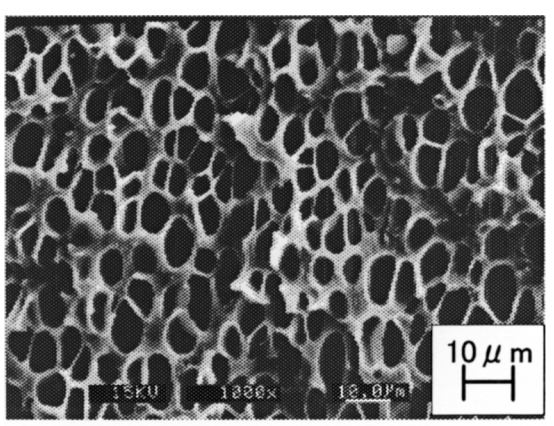

(a) Decompression rate:25MPa/s

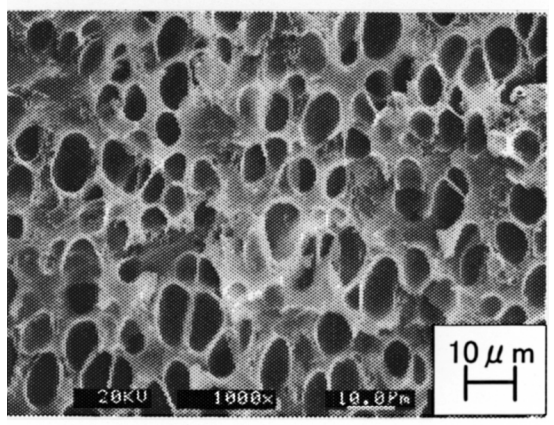

(b) Decompression rate: $10 \mathrm{MPa} / \mathrm{s}$

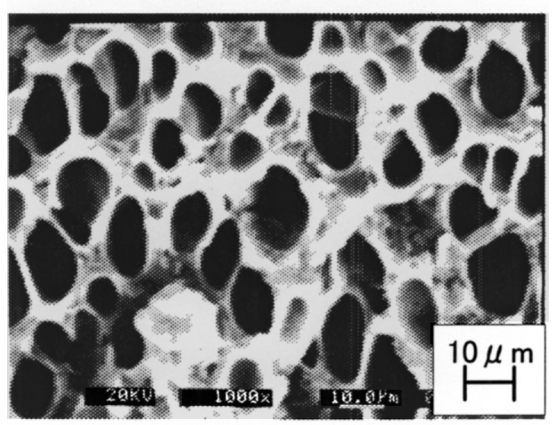

(c) Decompression rate: $1.6 \mathrm{MPa} / \mathrm{s}$

Soaking pressure: $15 \mathrm{MPa}$

Soaking time: $2 \mathrm{~h}$

Foaming temp.: $95^{\circ} \mathrm{C}$

Fig. 4 Microstructures of foamed PS changed decompression rates

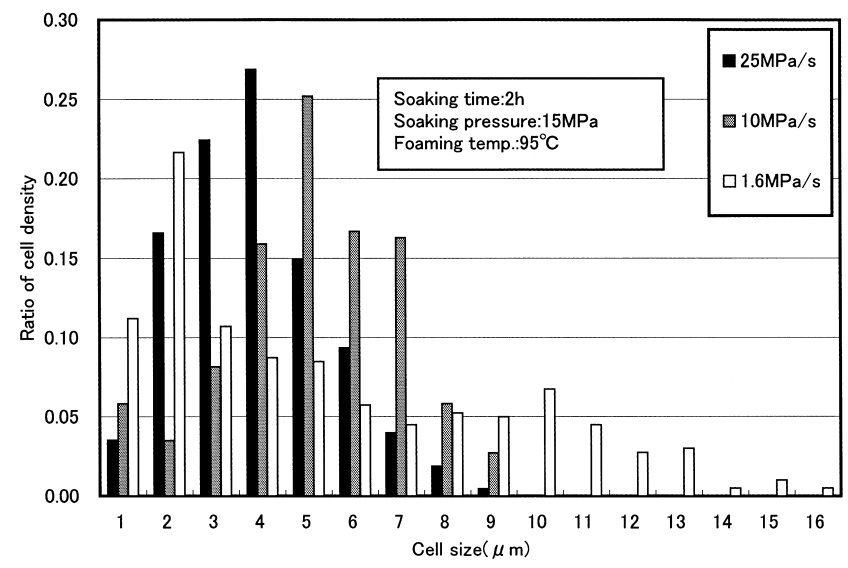

Fig. 5 Distributions of cell size under various decompression rates

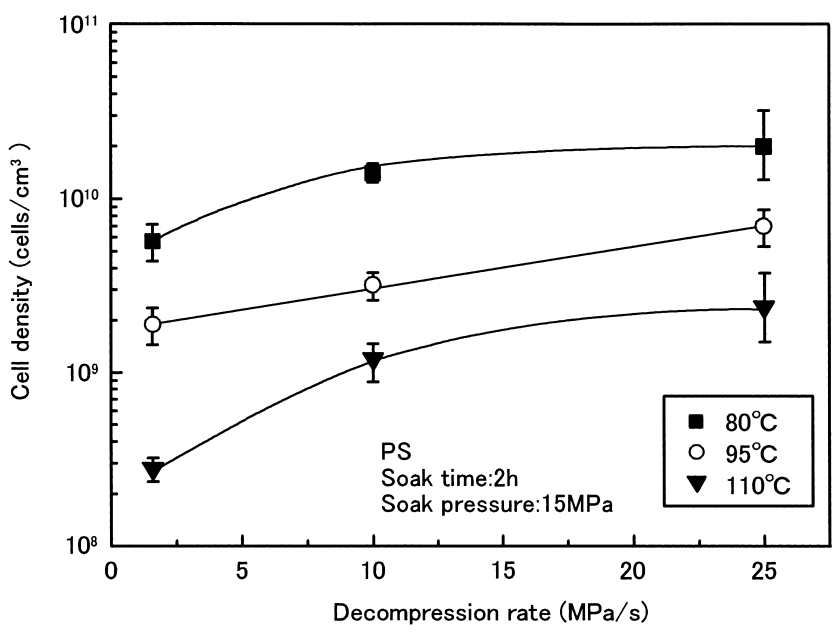

Fig. 6 Relationship between cell density and decompression rates under various foaming temperatures

部の気泡密度，横軸に減圧速度をとり，発泡温度別に得ら れた気泡密度の増減関係を示している。この図に示すよう にデータのバラッキは多少あるが，いずれの温度条件下に 沶いても減圧速度が速くなるにつれ気泡密度が大きくなり， そして発泡温度が低い程気泡密度が大きくなることがわか る. 減圧速度が速い場合は, 減圧速度が速い程一定圧力か ら減圧した場合の単位時間当たりの圧力差が大きくなるこ とから初期気泡核の発生率が増加し，その結果として気泡 密度も増大するものと考えられる。

\section{2 気泡密度に及ぼす発泡温度}

図 7 に減圧速度を一定とし, 発泡温度を変化させたとき の PS 発泡体のSEM 写真を示す。同図の (a) は発泡温度 $80^{\circ} \mathrm{C}$, (b) は発泡温度 $95^{\circ} \mathrm{C}$ そて (c) は発泡温度 $110^{\circ} \mathrm{C}$ の 場合の発泡体内部構造を表している。これらの図から, 発 泡温度が高くなる程気泡径は大きく, 気泡密度が小さくな る傾向が見られる。これらの傾向を詳しく検討するため， 同図に示したSEM 写真を画像解析し, 気泡径㧍よび気泡 密度を算出した。

図 8 に減圧速度 $25 \mathrm{MPa}$ で発泡温度を種々変化させたと きのPS 発泡体の気泡径分布を示す．同図は縦軸に総気泡 数と各気泡径に占める気泡数の比をとり, 横軸に気泡径を とり, 発泡温度を変化させたときの各気泡径が発泡体内部 に占める割合を示している。この結果から発泡温度が高く なるほど気泡径は大きくなり，広範囲に分布することがわ かる.

図 9 に種々の一定の減圧速度で，発泡温度を変化させた ときの PS 発泡体の気泡密度を示す。同図は縦軸に発泡体 内部の気泡密度, 横軸に発泡温度をとり, 減圧速度別に得 られた気泡密度の増減関係を示している。この戝に示すよ うにデータのバラッキは多少あるが，いずれの減圧速度下 においても発泡温度が高いほど気泡密度が減少することが わかる. この理由として, 高温時における発泡剤の飽和含 浸量の減少による気泡核の発生率の減少も考えられるが, 発泡温度が高い場合は樹脂が粘弾性挙動を示して軟化し, 気泡の合一が促されるためと考えられる。つまり，発泡温 度が高いほど減圧直後に成長した気泡同士が初期の間に合 


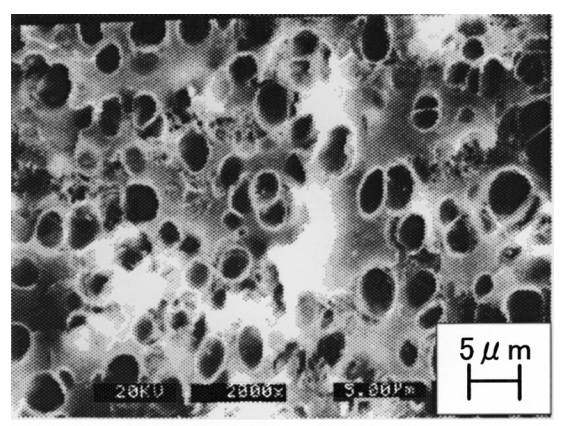

(a) Foaming temp.: $80^{\circ} \mathrm{C}$

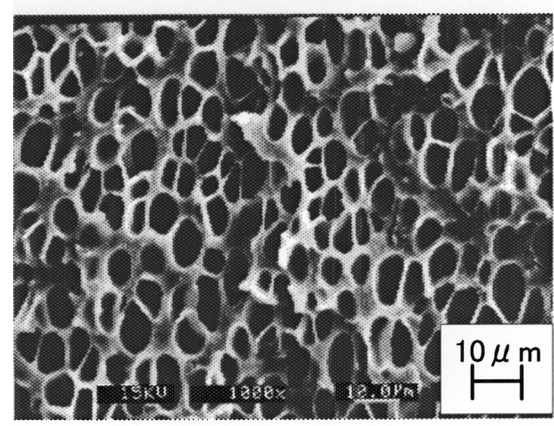

(b) Foaming temp.: $95^{\circ} \mathrm{C}$

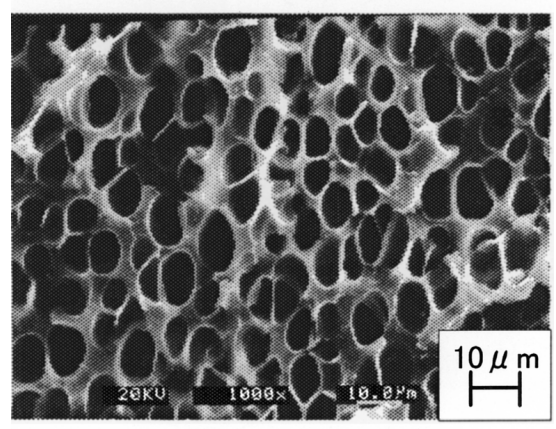

(c) Foaming temp.: $110^{\circ} \mathrm{C}$

Soaking pressure: $15 \mathrm{MPa}$

Soaking time: $2 \mathrm{~h}$

Decompression rate: $25 \mathrm{MPa} / \mathrm{s}$

Fig. 7 Microstructures of foamed PS changed foaming temperatures

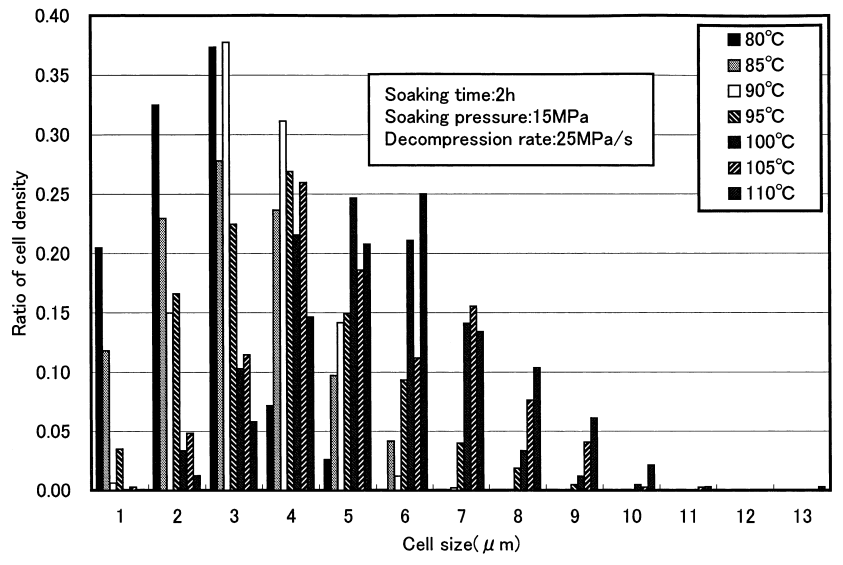

Fig. 8 Distributions of cell size under various foaming temperatures

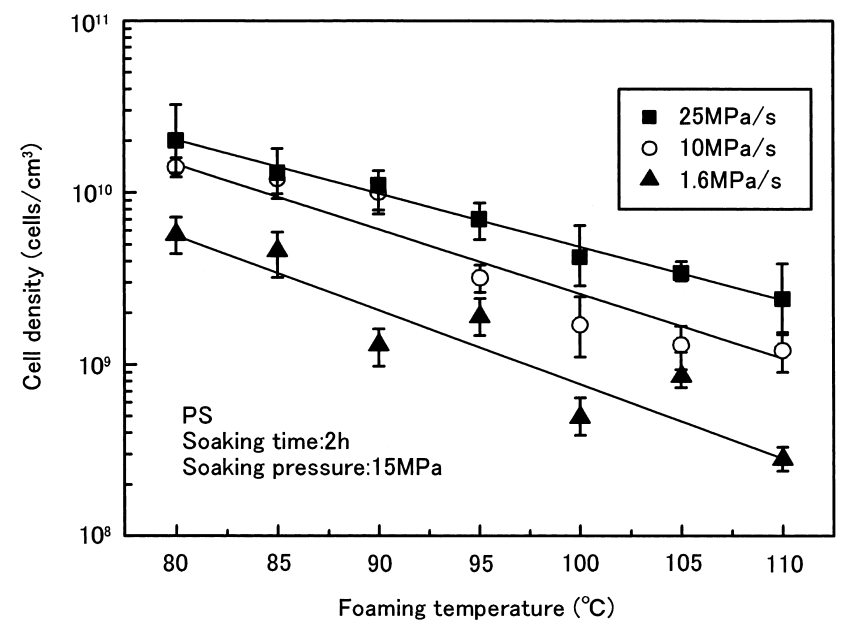

Fig.9 Relationship between cell density and foaming temperatures under various decompression rates

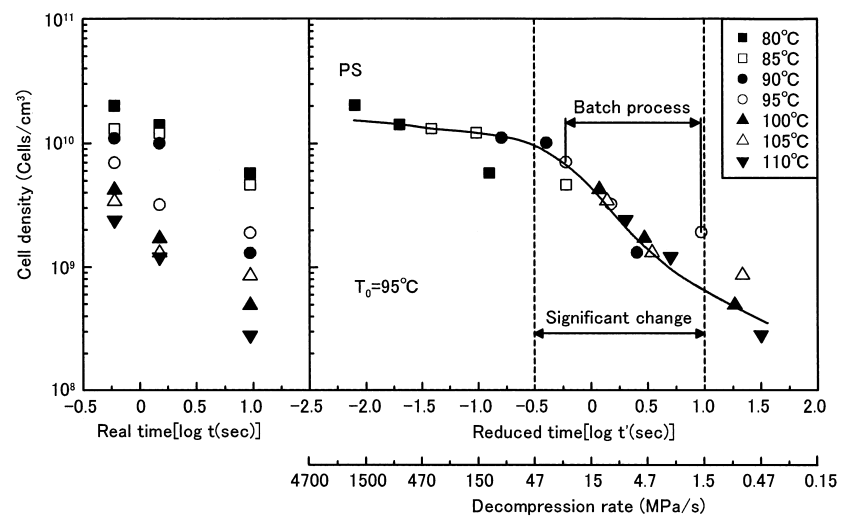

Fig. 10 Master curve of cell density of foamed PS

一しながら成長することから，結果として最終的に成長が 停止した時の気泡密度が減少するものと思われる.

上述の結果から, PS 発泡体の気泡密度は発泡温度が低 い程, 減圧速度が速いつまり減圧時間が短い程多く, そし て発泡温度が高い程，減圧速度が遅いつまり減圧時間が長 い程少なくなる時間および温度依存性があることがわかる.

\section{3 気泡密度に関する時間と温度の相関性}

4.1，4.2 節の結果を基に，PS 発泡体の気泡密度につい て発泡温度と減圧速度(減圧時間) の相関性を検討した。 図 10 にPS 発泡体の気泡密度のマスター曲線を示す。同 図の左側は縦軸に気泡密度，横軸に減圧時間を対数でとり, 減圧時間 (減圧速度) を変化させたときの温度別に得られ たPS 発泡体の気泡密度の増減関係を示している。同図の 右側は，左側に示す $95^{\circ} \mathrm{C}$ の PS 発泡体の気泡密度を基準 とし， $95^{\circ} \mathrm{C} よ り$ 温度の低い值は短時間側に， $95^{\circ} \mathrm{C} よ り$ 温 度の高い值は長時間側に時間軸に平行にそれぞれ重なり合 うように移動させて作成したものである。この図に示すよ うに, 多少の偏差はあるが PS 発泡体の気泡密度に関して 一本のマスター曲線を得ることができた。 また，図 $11 に$ PS 発泡体の気泡密度のマスター曲線を作成した際の移動 量を示す。この図に示すように, PS 発泡体の気泡密度の 時間と温度の移動因子はアーレニウス型で近似できること がわかる.これらのことから PS 発泡体の気泡密度には時 間と温度に相関関係が成立することがわかる。 


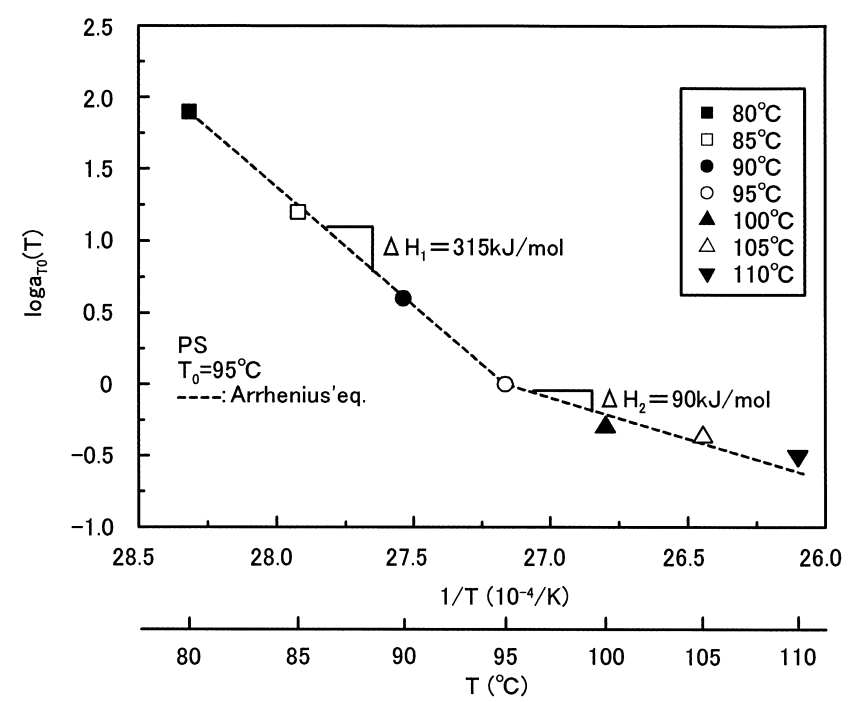

Fig. 11 Time-temperature shift factor of cell density of foamed PS

図 10 に示す PS 発泡体の気泡密度のマスター曲線に減 圧時間に対応する減圧速度を併記している。この図より, PS 発泡体の気泡密度は発泡温度が気泡成長の限界となる ガラス転移温度に近い低温側の粘弾性領域で, かつ減圧速 度が速い程大きくすることができることがわかる，そして， 気泡密度に関する時間と温度の相関性から, 任意の気泡密 度を有する発泡体を成形する際に必要な成形条件の予測が 可能であることがわかる。しかし, PS 発泡体の気泡密度 は，減圧速度を $1.6 〜 47 \mathrm{MPa} / \mathrm{s}$ の範囲で制御したとき著 しく増加するが, 減圧速度を $47 \mathrm{MPa} / \mathrm{s}$ 以上と速く制御し ても, 期待されるほどの気泡密度の増加は見られないこと も伺える.

本実験における発泡体に最終的に残る気泡密度に関する 減圧速度(減圧時間) 並びに温度に関する検討は, 発泡プ ロセスを限定し，かつ実験条件についても狭い範囲で行っ ていることから, 今後の精度並びに信頼性向上に対してこ れらの範囲を広げることと他の樹脂についてのさらなる検 討が必要である。

\section{5. 結言}

本研究は, 試料にガラス転移温度以上の高温下で, 発泡 剂を高圧で飽和含浸させ，その後減圧と共に気泡核生成，
気泡成長を行い，冷却により気泡成長を停止するプロセス を取り上げ，発泡体に最終的に残る気泡密度に関する発泡 温度と減圧時間（減圧速度）の関係を検討した. その結果， 以下のことが明らかとなった。

1.PS 発泡体の気泡密度は発泡温度が低く, 減圧速度が 速いつまり減圧時間が短いとき増加する。 また, 発泡 温度が高く, 減圧速度が遅い, つまり減圧時間が長い とき減少する時間および温度依存性を示す。

2. PS 発泡体の気泡密度の温度依存性と時間依存性の間 には相関性があり，一本のマスター曲線で表現するこ とができる。

3. PS 発泡体の気泡密度は発泡温度が気泡成長の限界と なるガラス転移温度に近い低温側の粘弾性領域で，か つ減圧速度が速い程増加することができる。

4. PS 発泡体の気泡密度に関する時間と温度の相関性を 基に，任意の気泡密度を有する発泡体を成形する際に 必要な成形条件の予測が可能である.

\section{参 考 文 献}

1 ) Martini, J., Waldman, F. and Suh, N. P. : U.S. Patent 4473665 (1982)

2 ) Colton, J. and Suh, N. P. : Advanced Manufacturing Processes, 1 (3), 314 (1986)

3 ) 渡辺一郎：プラスチック成形加工学会, 第 54 回講演 会, 6(2000)

4 ）津田文朗：プラスチックエージ，47，123(2001)

5 ) Trexel Inc. : www.trexel.com (2001)

6 ) Colton, J. and Suh, N. P. : Polymer Eng. \& Sci., 27 (7), $485(1987)$

7 ）新保 實：材料システム， 18，5(1999)

8 ）新保 實：成形加工，13(2)，90(2001)

9 ) 稲森康次郎, 葉山 薰, 高田光子, 大嶋正裕, 谷垣昌 敬：成形加工，11(3)，194(1999)

10）藤城敏弘, 新保 實, 村上太一：成形加工シンポジア '01, 17 (2001)

11) Goel, S. K. and Beckman, E. J. : Polymer Engineering and Science, 34(14), 1137 (1994)

12）瀧健太郎，大嶋正裕：成形加工’03，91(2003)

13）川島秀隆，新保 實：材料システム，21，69(2003) 